\title{
Analisis dan Desain Sistem Informasi Pembayaran Sumbangan Pembinaan Pendidikan (SPP) di SMK Avicena Rajeg
}

\author{
Rohmat Taufiq ${ }^{1}$, Diyah Ayuni Magfiroh², Dadang Yusup ${ }^{3}$, Yulianti ${ }^{4}$ \\ ${ }^{1,2}$ Teknik Infomatika, Fakultas Teknik, Universitas Muhammadiyah Tangerang, Tangerang, Indonesia, \\ 15117 \\ ${ }^{3}$ Informatika, Fakultas Ilmu Komputer, Universitas Singaperbangsa, Karawang, Indonesia, 411361 \\ ${ }^{4}$ Teknik Informatika, Universitas Pamulang, Serpong, Tangerang Selatan, Banten, Indonesia, 15310 \\ email: 'rohmat.taufiq@umt.ac.id; 2dyahayumagf@gmail.com; ${ }^{3}$ dadang.dyf@ staff.unsika.ac.id; \\ 4yulianti@unpam.ac.id
}

Submitted Date: January $30^{\text {th }}, 2020$

Revised Date: January $31^{\text {st }}, 2020$
Reviewed Date: January $30^{\text {th }}, 2020$

Accepted Date: January $31^{\text {st }}, 2020$

\begin{abstract}
As the present era progresses, information technology (IT) is expanding enormously. In the world of education, mainly primary and secondary school, some jobs carried out manually. SMK Avicena Rajeg is a place where the writer carried out practical work, still inputting data using Microsoft excel - analyzing the SPP payment information system in SMK Avicena Rajeg which is means for supporting TU staff performance. The method used by the writer includes interview method, observation method, literature method and Unified Modelling Language (UML) to describe a running model system and proposed system. With the production of an SPP payment information system analysis in the discussion that the writer described could be used as consideration in the process of developing student payment information systems. The writer suggested that the student tuition payment process should be computerized, as of the data that managed can be well-integrated, for example, by using the PHP programming language and MySQL database server.
\end{abstract}

Keywords: Information System, SPP Payment, School, SMK, UML

\section{Abstrak}

Seiring perkembangan zaman saat ini, perkembangan teknologi informasi (IT) sangat berkembang pesat. Dalam dunia pendidikan, khususnya sekolah terdapat beberapa pekerjaan yang dilakukan dengan cara manual. SMK Avicena Rajeg adalah tempat di mana penulis melaksanakan kerja praktek, masih memasukkan data dengan menggunakan Microsoft Excel. Menganalisa sistem informasi pembayaran SPP pada SMK Avicena Rajeg merupakan sarana untuk menunjang kinerja para staff TU. Metode yang digunakan penulis meliputi metode wawancara, metode observasi, metode kepustakaan dan Unified Modeling Language (UML) untuk mendeskripsikan model sistem yang berjalan dan sistem usulan. Dengan dihasilkannya sebuah analisa sistem informasi pembayaran SPP pada pembahasan yang penulis jabarkan dapat digunakan sebagai bahan pertimbangan dalam proses pengembangan sistem informasi pembayaran siswa. Penulis menyarankan bahwa proses pembayaran SPP siswa sebaiknya dilakukan secara terkomputerisasi, sehingga data yang dikelola dapat terintegrasi dengan baik, misalnya dengan menggunakan bahasa pemrograman PHP dan server database MySQL.

Kata Kunci: Sistem Informasi, Pembayaran SPP, Sekolah, SMK, UML

\section{Pendahuluan}

Seiring perkembangan zaman saat ini, perkembangan teknologi informasi (IT) sangat berkembang pesat, bahkan perkembangannya dapat dihitung dalam hitungan hari saja. Bentuk perkembangan dari teknologi informasi saat ini juga sudah beragam. Misalnyanya saja, perkembangan penggunaan komputer yang terkoneksi internet (website), teknologi untuk mendukung infrastruktur telekomunikasi, dan lainlain. Hal ini dikarenakan kebutuhan akan teknologi dan informasi sangat tinggi untuk membantu 
berbagai jenis bidang pekerjaan manusia, salah satunya adalah bidang pendidikan. Teknologi informasi ditujukan untuk membantu pekerjaan dengan menyediakan informasi dan melakukan berbagai tugas yang berhubungan dengan pengolahan informasi (Hanum \& Saifudin, 2019).

Dalam perkembangan teknologi saat ini, komputer menjadi salah satu media elektronik yang memiliki peranan yang sangat penting, serta terus menerus mendominasi berbagai proses kerja agar dapat lebih mudah, efektif dan efesien. Dalam kehidupan sehari-haripun semua serba komputerisasi. Seperti di sekolah-sekolah, kantor, pusat perbelanjaan, dan lain-lain yang telah menggunakan sistem komputerisasi. Salah satu contoh penerapan di sekolah adalah aplikasi perpustakan yang dapat mempercepat proses pengolahan data perpustakaan (Salsabilah \& Yulianti, 2019). Dengan adanya sistem terkomputerisasi ini diharapkan dapat memudahkan dalam segala aspek kehidupan.

Sistem informasi merupakan sekumpulan sistem-sistem yang saling terintregasi satu sama lain untuk menghasilkan suatu informasi yang dapat berguna bagi pemakainya. Dengan sistem informasi maka data dan informasi akan tersimpan dalam suatu database sistem sehingga data menjadi teratur serta memudahkan pemakai apabila membutuhkan data tersebut. Oleh karena itu hampir semua kalangan instansi saat ini memanfaatkan sistem termasuk juga dalam dunia pendidikan.

Dalam dunia pendidikan, khususnya sekolah terdapat beberapa pekerjaan yang dilakukan dengan cara komputerisasi, salah satunya adalah pembayaran SPP yang pengolahan datanya menggunakan Microsoft Excel untuk mencatat dan juga pembayaran SPP siswa. SPP merupakan singkatan dari sumbangan pembinaan pendidikan, yaitu dana yang disumbangkan untuk berlangsungnya kegiatan pendidikan disuatu instansi.

SMK Avicena Rajeg adalah tempat di mana penulis melaksanakan kerja praktek, SMK Avicena Rajeg adalah salah satu sekolah swasta yang berlokasi di Jl. Raya Rajeg - Mauk KM.1, Ds. Sukamanah, Kec. Rajeg, Kab. Tangerang. Proses pencatatan pada pembayaran SPP disekolah yang penulis teliti menggunakan Microsoft Excel sebagai alat hitung, pembuatan tabel, pengetikan dan penyimpanan data. Pemasukan data dengan menggunakan Microsoft Excel membutuhkan ketelitian dan waktu yang relatif lama dan sebagai media penyimpanan yang relatif kurang aman karena dapat digunakan oleh siapa saja.
Hal tersebut merupakan suatu masalah yang dapat menyebabkan kurangnya efesiensi dan efektifitas kinerja sebuah database seperti dapat timbulnya kesalahan data, duplikasi data dan hilangnya data. Oleh karena itu dilakukan penelitian dengan judul "ANALISIS SISTEM INFORMASI PEMBAYARAN SPP PADA SMK AVICENA RAJEG".

\section{Landasan Teori}

Analisis sistem adalah penguraian dari suatu sistem yang utuh ke dalam bagian-bagian komponennya dengan maksud untuk mengidentifikasikan dan mengevaluasi permasalahan-permasalahan, kesempatankesempatan, hambatan-hambatan yang terjadi dan kebutuhan-kebutuhan yang diharapkan sehingga dapat dibuat rancangan sistem yang baru yang sesuai dengan kebutuhan. Menurut Taufiq (2013) sistem adalah kumpulan dari sub-sub sistem baik abstrak maupun fisik yang saling terintegrasi dan berkolaborasi untuk mencapai suatu tujuan tertentu sedangakn informasi adalah data-data yang diolah sehingga memiliki nilai tambah dan bermanfaat bagi pengguna.

Sistem informasi adalah kumpulan dari subsub sistem yang saling terintegrasi dan berkolaborasi untuk menyelesaikan masalah tertentu dengan cara mengolah data sehingga memiliki nilai tambah dan bermanfaat bagi pengguna (Taufiq, 2018)

Sistem informasi merupakan sebuah kombinasi dari manusia, perangkat keras (hardware), perangkat lunak (software), jaringan komunikasi, sumber data, kebijakan, dan prosedur yang memiliki kemampuan untuk mengumpulkan, menyimpan, mengubah, dan menyebarluaskan informasi dari sebuah organisasi.

SPP (Sumbangan Penunjang Pendidikan) adalah iuran atau pembayaran setiap bulan dari siswa yang menjadi kewajiban bagi siswa di sekolah. Pembayaran SPP tersebut diambil berdasarkan kesepakatan rapat Komite sekolah dan orang tua siswa. Pembayaran SPP ditunjukkan untuk menunjang peningkatan mutu pendidikan yang terkait dengan sarana dan prasarana kegiatan belajar mengajar.

Pada perkembanagn teknik pemograman berorientasi objek, muncullah sebuah standarisasi bahasa pemodelan untuk pembangunan perangkat lunak yang dibangun dengan menggunakan teknik pemograman berorientasi objek yaitu Unified Modeling Language (UML). 


\section{Metode Penelitian}

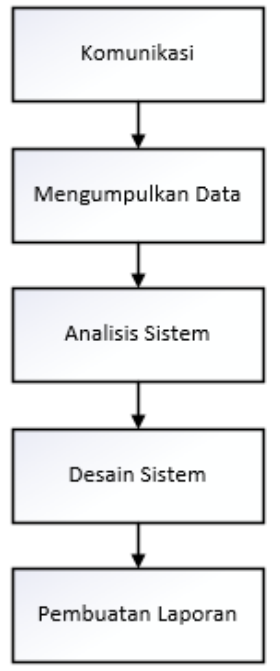

Gambar 1 Metode Penelitian

Pada pengembangan Sistem Informasi Pembayaran Sumbangan Pembinaan Pendidikan (SPP) di Di SMK Avicena Rajeg dilakukan secara bertahap, yaitu:

\section{A. Usulan Prosedur yang Baru}

Setelah menganalisis sistem yang berjalan pada SMK Avicena Rajeg Kabupaten Tangerang, terdapat beberapa kekurangan dalam proses pembayaran SPP siswa terutama dalam proses pencatatan dan pembuatan laporan. Maka selanjutnya akan dibahas mengenai rancangan usulan sistem yang akan dibangun.

Rancangan prosedur yang diusulkan bertujuan untuk menyempurnakan dan memberikan alternatif dalam memberikan informasi juga mempermudah staff TU dalam pemasukan data secara terkomputerisasi, memudahkan siswa atau wali murid dalam mengecek pembayaran SPP yang dapat diakses di mana pun dan kapanpun, serta memudahkan Kepala Sekolah dalam mereview laporan.

Perbedaan sistem yang berjalan dengan sistem yang diusulkan semoga akan memberikan dampak positif bagi pihak yang menggunakannya, supaya dalam pelaksanaannya pembayaran SPP bisa lebih efektif dan efesien. Adapun perancangan sistem yang coba diusulkan ini dibuat dengan menggunakan $U M L$.

\section{B. Diagram Rancangan Sistem}

Rancangan sistem ini adalah tahapan perancangan sistem yang akan dibentuk yang dapat berupa penggambaran proses-proses suatu elemenelemen dari suatu komponen. Proses perancangan ini merupakan suatu tahapan awal dari perancangan aplikasi dari sistem pembayaran SPP.

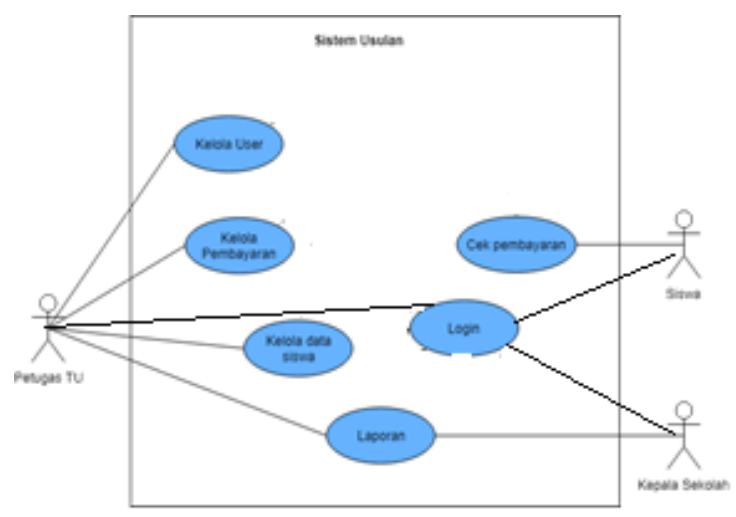

Gambar 2 Use Case Diagram Sistem yang
Diusulkan

Pada Gambar 2 Use Case Diagram Sistem yang Diusulkan, ada beberapa actor yang terlibat dalam sistem. Di antaranya adalah Petugas TU, Siswa dan Kepala Sekolah. Aktor dapat menggunakan sistem sesuai use case yang diasosiasikan. Ketika sistem pertama dijalankan, semua fungsi/menu dinonaktifkan. Setelah login dan berhasil, maka fungsi/menu diaktifkan sesuai aktor yang login. Sehingga aktor dapat menggunakan sistem sesuai haknya.

Tabel 1 Penjelasan Aktor Use Case Diagram

\begin{tabular}{|l|l|l|}
\hline No. & Actors & \multicolumn{2}{|c|}{ Deskripsi } \\
\hline 1. & Petugas TU & $\begin{array}{l}\text { Menginput pembayaran, } \\
\text { mengelola data siswa, } \\
\text { mengelola user dan } \\
\text { melakukan rekap laporan } \\
\text { pembayaran dan tunggakan } \\
\text { siswa. }\end{array}$ \\
\hline 2. & Siswa & \begin{tabular}{l} 
Mengecek pembayaran \\
\hline 3.
\end{tabular} \\
$\begin{array}{l}\text { Kepala } \\
\text { Sekolah }\end{array}$ & $\begin{array}{l}\text { Mendapatkan hak akses } \\
\text { untuk me-review laporan } \\
\text { pembayaran dan tunggakan } \\
\text { siswa. }\end{array}$ \\
\hline
\end{tabular}

Pada Gambar 3-8 yaitu Statechart Diagram dan Activity Diagram yang digunakan untuk menggambarkan proses alur sistem yang diusulkan untuk SMK Avicena Rajeg. Diagram ini mengandung aktifitas dari masing-masing usecase pada Usecase Diagram yang diusulkan. Gambar Statechart Diagram dan Activity Diagram pada jurnal ini hanya beberapa saja, gambar lengkap dari diagram terdapat didalam paper. 


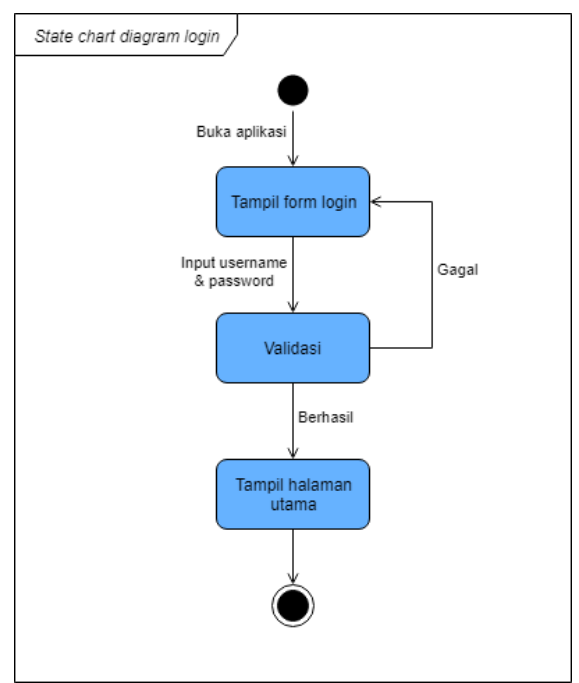

Gambar. 3 Statechart Diagram Login

Deskripsi Gambar 3. Tampilan login akan muncul jika user masuk ke website terlebih dahulu dan ingin melakukan login sistem. User harus menginput username beserta password (untuk petugas TU) dan NIS beserta password (untuk siswa) jika ingin masuk ke sistem sesuai hak akses masing-masing.

Setelah user menginput maka sistem akan melakukan validasi. Jika sesuai maka sistem akan menampilkan menu utama sesuai hak akses masing-masing. Dan jika validasi gagal maka sistem akan kembali menampilkan tampilan login beserta pesan kesalahan.

Dalam tampilan utama setelah login untuk staff TU, sistem akan menampilkan halaman utama pembayaran SPP berisi menu kelola user, kelola pembayaran, kelola data siswa, laporan pembayaran dan logout.

Sedangkan untuk siswa atau wali murid, sistem akan menampilkan halaman utama cek pembayaran berisi menu cek pembayaran, cetak kwitansi, detail rincian, profil dan logout.

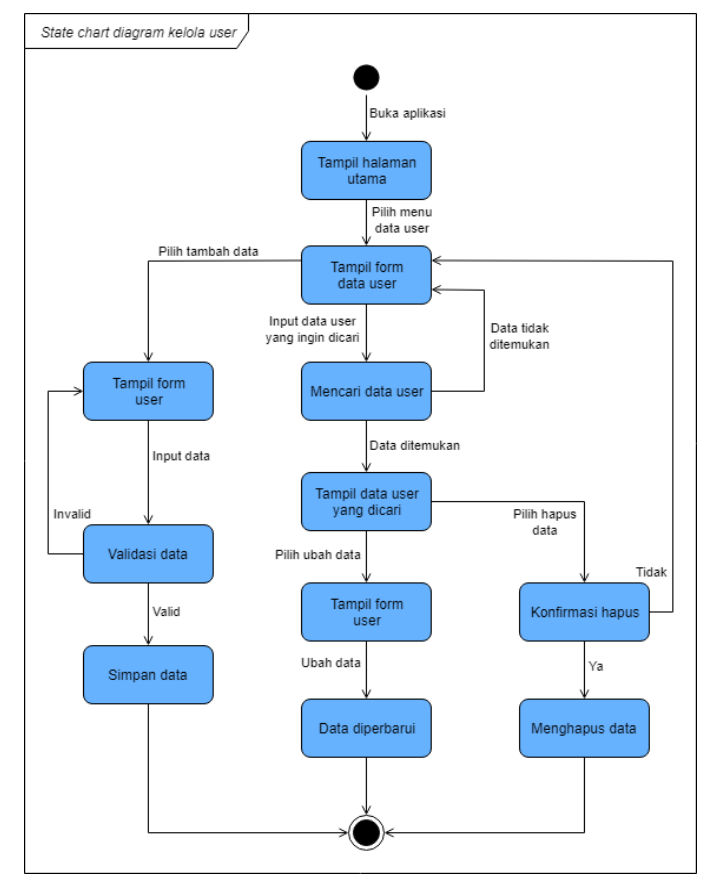

Gambar. 4 Statechart Diagram Kelola User

Deskripsi Gambar 4. Tampilan menu kelola user akan muncul jika staff TU berhasil masuk ke website setelah menginput username beserta password.

Dalam menu kelola user, staff TU dapat menambahkan data user baru untuk cek pembayaran yang dilakukan oleh siswa. Dan melakukan pencarian data untuk proses ubah data atau hapus data user.

Proses dari kelola user sendiri cukup panjang karena adanya CRUD (Create, Read, Update and Update) yang merupakan dasar dari suatu pengelolaan. Penjelasan dari CRUD pada Activity Diagram kelola user adalah sebagai berikut:

- Create berarti staff TU bisa menambahkan data user baru.

- Read berarti staff TU bisa mengecek data dari user dengan melakukan pencarian data terlebih dahulu.

- Update berarti staff TU bisa melakukan perubahan data pada data user yang diiinginkan dengan melakukan pencarian data terlebih dahulu.

- Delete berarti staff TU bisa menghapus data user yang diinginkan dengan melakukan pencarian data terlebih dahulu. 


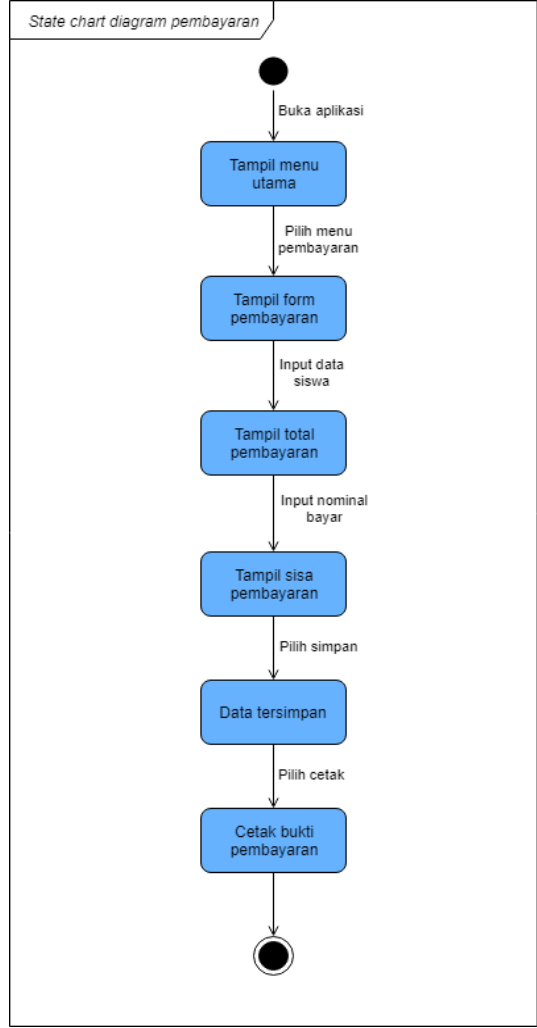

Gambar. 5 Statechart Diagram Pembayaran

Deskripsi Gambar 5. Tampilan menu kelola pembayaran akan muncul jika staff TU berhasil masuk ke website setelah menginput username beserta password.

Dalam menu kelola pembayaran, staff TU harus terlebih dulu menginput data siswa yang sudah melakukan pembayaran SPP. Setelah itu sistem akan menampilkan data pembayaran siswa yang sudah diinput. Dan staff TU kembali menginput data yang berupa nominal pembayaran dan sistem tentu akan menampilkan sisa dari pembayaran siswa yang sudah membayar.

Setelah proses pemasukan selesai maka staff TU harus memilih simpan terlebih dahulu agar data pembayaran dapat diperbarui oleh sistem. Kemudian staff TU dapat memilih proses selanjutnya yang akan dilakukan.

Staff TU dapat hanya melakukan menyimpan data pembayaran saja atau mau mencetak data pembayaran yang sudah diproses tadi.

Jika staff TU memilih mencetak data pembayaran maka sistem akan menampilkan keluaran (output) dari masukan (input) yang sudah disimpan tadi dan langsung memproses cetak dari data pembayaran.

Untuk hasil cetak data kelola pembayaran ini, hanya sebagai data backup untuk pihak sekolah jikalau ada hal yang tidak diinginkan terjadi. Baik dalam kesalahan dari staff TU maupun kerusakan dari sistem sendiri.

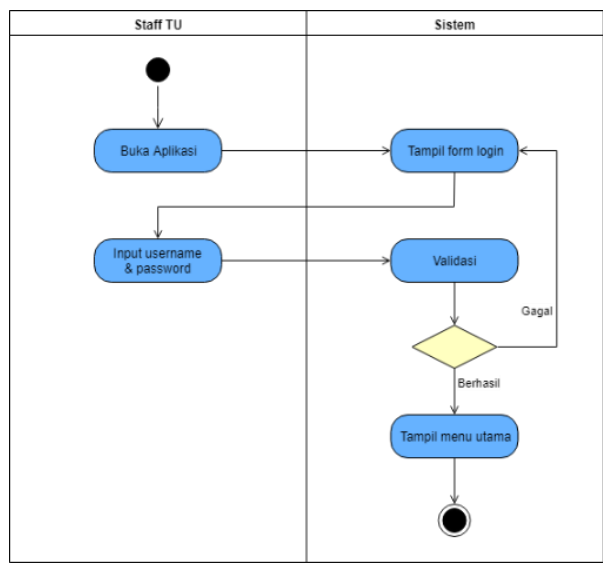

Gambar. 6 Activity Diagram Login

Deskripsi untuk Gambar 6 sama dengan deskripsi dari Gambar 3.

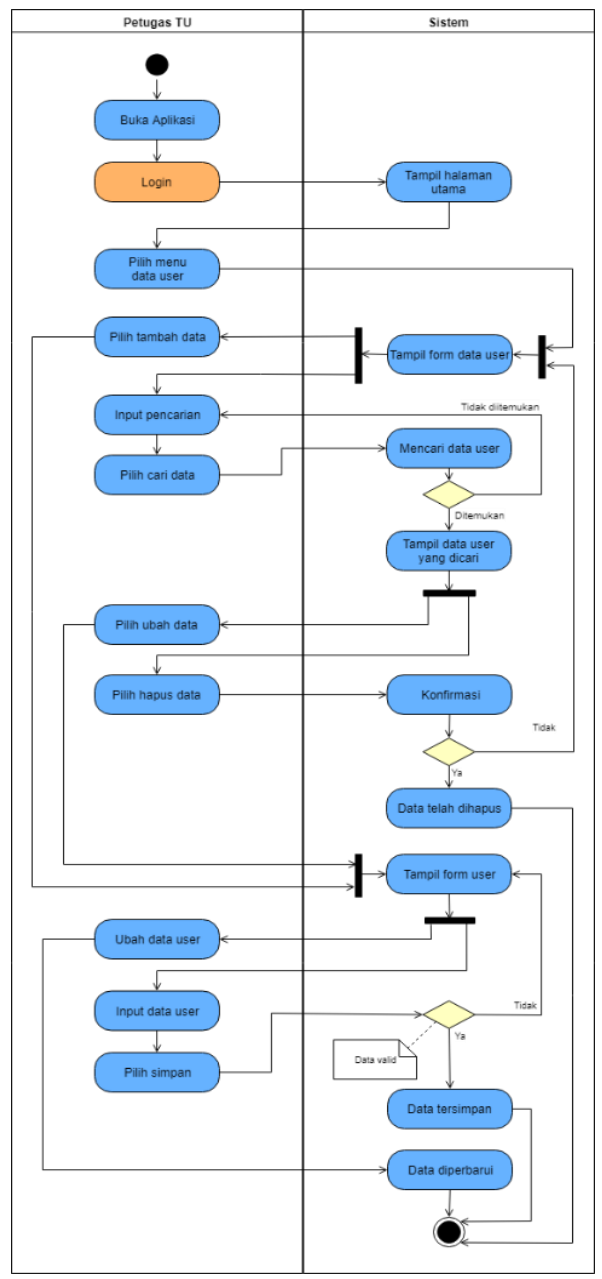

Gambar. 7 Activity Diagram Kelola User 
Deskripsi untuk Gambar 7 sama dengan deskripsi dari Gambar 4.

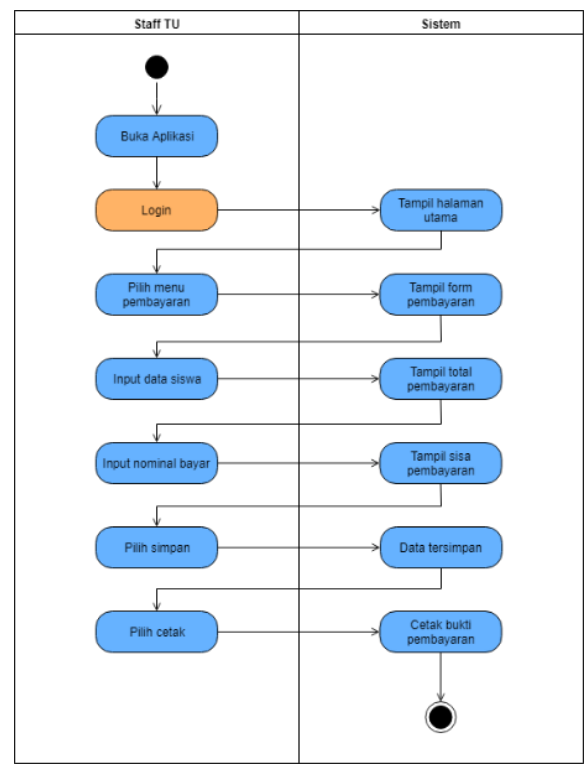

Gambar. 8 Activity Diagram Kelola Pembayaran

Deskripsi untuk Gambar 8 sama dengan deskripsi dari Gambar 5.

\section{Hasil dan Pembahasan}

Hasil pengembangan Sistem Informasi Pembayaran Sumbangan Pembinaan Pendidikan (SPP) di Di SMK Avicena Rajeg memiliki antarmuka seperti ditunjukkan pada Gambar 9 sampai Gambar 14. Antarmuka aplikasi antara lain:

1. Antarmuka Sistem Pembayaran

Gambar 9 menunjukkan antarmuka untuk login staf dan kepala sekolah. Gambar 10 antarmuka untuk pembayaran. Gambar 11 antarmuka untuk data user.

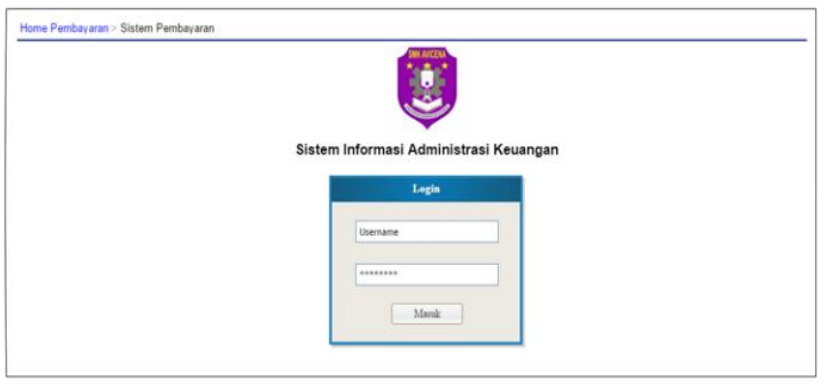

Gambar. 9 Antarmuka Sistem Login

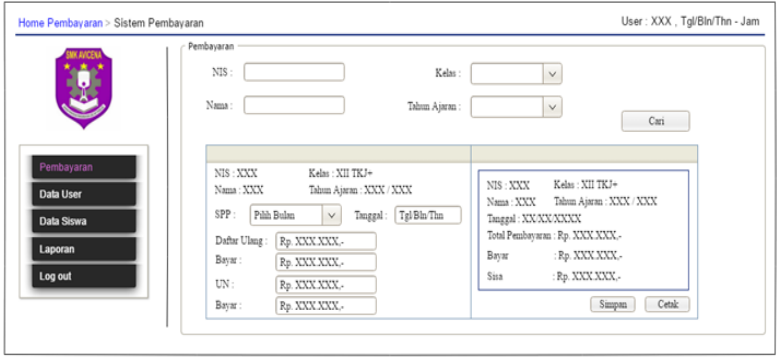

Gambar. 10 Antarmuka Menu Pembayaran

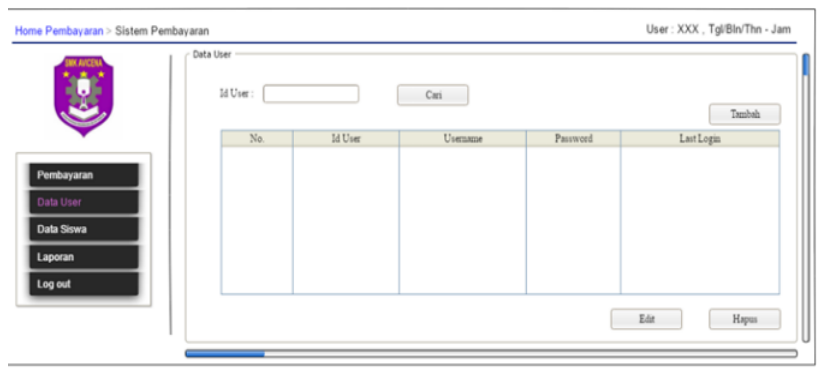

Gambar. 11 Antarmuka Menu Data User

2. Desain Antarmuka Cek Pembayaran Gambar 12 antarmuka untuk login siswa. Gambar 13 untuk pengecekan pembayaran. Dan Gambar 14 antarmuka untuk detail rincian pembayaran.

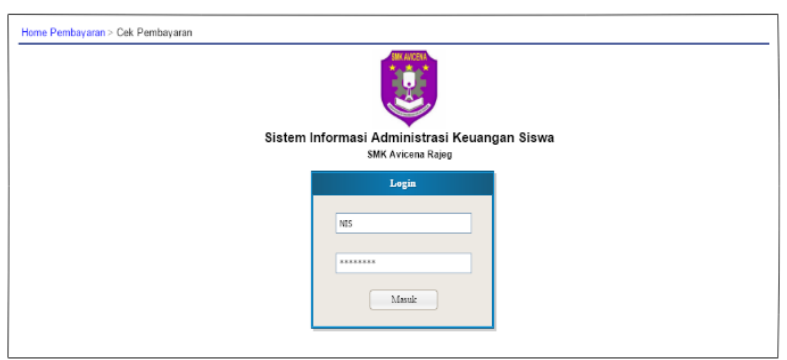

Gambar. 12 Antarmuka Menu Login

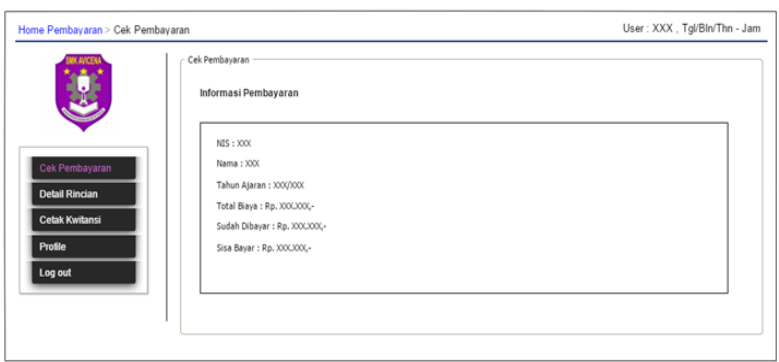

Gambar. 13 Antarmuka Menu Cek Pembayaran 


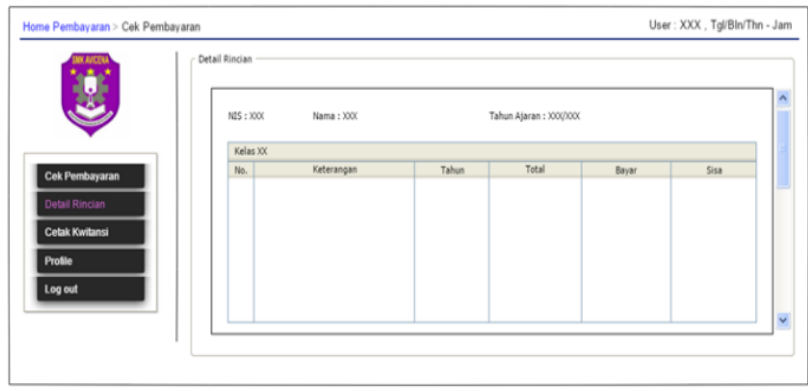

Gambar. 14 Antarmuka Menu Detail Rincian

\section{Kesimpulan}

Berdasarkan hasil penelitian yang dilakukan pada sistem pembayaran SPP SMK Avicena Rajeg, maka dapat disimpulkan sebagai berikut:

1. Masih menggunakan pencatatan manual yaitu dengan memasukkan data ke dalam Microsoft Excel, yang mana proses ini membutuhkan waktu yang lama, kurang efektif dan efisien dalam pembuatan laporan serta tidak adanya back-up data apabila terjadi hal-hal yang tidak diinginkan. Dan penggunaan dari Microsoft Excel belum bisa dilihat secara realtime.

2. Pada pembahasan yang sudah dipaparkan sebelumnya, perancangan dari sistem informasi pembayaran SPP pada SMK Avicena Rajeg memudahkan staff TU dalam melakukan proses pembayaran siswa serta memudahkan staff TU maupun Kepala Sekolah untuk mereview laporan pembayaran SPP. Selain itu, siswa dan wali murid juga dapat mengecek pembayaran SPP secara online.

\section{Referensi}

Abdur, Achmad dan Nada, 2018, Perancangan Sistem Informasi Administrasi Pembayaran SPP Siswa Berbasis WEB di SMK Al-Amanah, Journal Sisfotek Global, Vol. 8 No. 1, Maret 2018 ISSN: 2088-1762, hal 51.

Hanum, W. S., \& Saifudin, A. (2019). Rancang Bangun Aplikasi Panduan Pariwisata di Kabupaten Banyuwangi Mobile Berbasis Android. Jurnal Teknologi Sistem Informasi Dan Aplikasi, 2(2), 59. https://doi.org/10.32493/jtsi.v2i2.2798

Henderi. Maimunah, R. Andrian (2011). "Desain Aplikasi E-Learning Sebagai Media Pembelajaran Artificial Informatics," Journal CCIT., vol. 3, no. 4, pp. 322.

H. Sudirman, E. Retnadi, R. Kurniawati, (2012). "Perancangan Program Aplikasi Transaksi Pembayaran SPP,UTS dan UAS Menggunkan Metode Analisis dan Desain Berorientasi Objek
Model Unified Approach(UA)," STT-Garut, vol. 9, no. 18, pp. 3, 2012.

Melia, Riyanto, dan Adi, 2012, Rancang Bangun Sistem Informasi Pembayaran Sumbangan Penunjang Pendidikan Di Smp Muhammadiyah I JeruklegiCilacap, Jurnal Telematika, Vol. 5 No. 1, Februari 2012, hal 105.

Salsabilah, Z., \& Yulianti, Y. (2019). Perancangan Aplikasi Perpustakaan Berbasis Web pada SMK Negeri 1 Rangkasbitung. Jurnal Teknologi Sistem Informasi Dan Aplikasi, 2(1), 9. https://doi.org/10.32493/jtsi.v2i1.2401

Taufiq, Rohmat. (2013). "Sistem Informasi Manajemen; Konsep Dasar, Analisis dan Metode Pengembangan". Yogyakarta: Graha Ilmu.

Taufiq, Rohmat. 2018. "Pengantar Sistem Informasi". Jakarta. Mitra Wacana Media. 